\title{
Implementation of The Classical Conditioning in PAI Learning
}

\author{
Baharuddin $^{1}$, Suyadi $^{2}$ \\ ${ }^{1,2}$ State Islamic University of Sunan Kalijaga Yogyakarta, Indonesia \\ 12aldhin.bahar@gmail.com, ${ }^{2}$ suyadi@uin-suka.ac.id
}

\begin{tabular}{ll}
\hline \hline & \multicolumn{1}{c}{ ABSTRACT } \\
\hline Keyword: & $\begin{array}{l}\text { SMAN } 1 \text { Teladan in the study of Islamic education uses the behavioristic } \\
\text { Implementation, }\end{array}$ \\
theory known as classical conditioning. This research aims to determine the \\
implementation of classical conditioning in the study of Islamic education \\
Islamic Education, \\
Learning.
\end{tabular}

\section{A. INTRODUCTION}

Learning of Islamic education is not able to give students any influence, if the study is not accompanied by the correct method. At SMAN 1 Teladan in the study of Islamic education using methods born of dog trials. The theory of the question is the behavioristic theory of the classical conditioning Pavlov (classic conditioning). The classical conditioning theory or the terms of Pavloving conditioning and classical conditioning are the same. In this theory the elements required for the birth of conditioning are the first, Unconditioned Stimulus (an imconditioned stimulus "US"), which raises the natural response of the organism. Secondly, unconditioned responce (The unconditioned response "UR") which is a natural or automatic response caused by Unconditioned Stimulus. Thirdly, conditioned stimulus (the stimulus conditioned "CS"), is a neutral stimulus because it does not cause natural response. When these elements are mixed in a certain way, there is a conditioned response. This theory was born to a scientist born in Russia. In Pavlov's view and other behaviorists the human beings are considered to have awareness that 
is no different from animals. Therefore, experiments on animals can be analogoed and generalized to humans.

According to the behavioristic Psychology of Learning is an instrumental control that comes from the environment. Learning whether someone depends on the conditional factors given by the environment.. In addition, behavioristic views are individuals as reactive beings. Creatures that respond to the environment. With these environmental experiences shaping the behavior (Zamzani, 2015:3) Related to classical conditioning study theory refers to continuous training, as stimulus and stimuli are present to replace other stimuli in developing response. In learning, the feelings of people learn vary and some are passive. Therefore, to conduct a response the need for a certain stimulus, while the strengthening according to Pavlov the uncontrollable stimulus has a relationship with strengthening. That Stimulus causes the strengthening of behaviour and serves as an amplifier (Zulhammi, 2015:111-112) In this theory of learning to be used, Pavlov has confidence in the principles of conditioning that can be used to describe a wide variety of phenomena. Particularly this theory relates these principles to personality, it is a view that the one fundamental thing to the differentiator between dogs and humans is the balance between inhibition and excitation (Hill, 2012:40). In addition in learning a teacher must be able to understand the behavior of the students. In understanding the behavior of a teacher must understand the stimulus one with the other. In the context of learning is reviewed from an Islamic education teacher is someone who is able to provide a religious understanding for the student, and the teacher is someone who gives the nutrients to the soul with science (Assegaf, 2014:111).

Research on classical conditioning has been widely researched by experts including research conducted by (Baharun, 2016:231-246), (Haslinda, 2019:87-99), (Huda, 2017:14-21), (Nahar, 2016:64-74), (Nurhidayati, 2012:23-43), (Rusuli, 2014:38-54), (Zulhammi, 2015:105127) The study tended to discuss classical conditioning and Islamic views on the theory, so the adoption of classical conditioning theory on Islamic religious education was neglected. This research explains the classical theories that are still relevant to be used in contemporary learning so that there is some focus raised that is exposing the application of classical conditioning in the study of Islamic Religious education at SMAN 1 Examples and factors that influence it. The purpose of this writing is based on the hypothesis that the study of Islamic education in SMAN 1 exemplary Yogyakarta has a special characteristic that is a distinguishing location with public schools in Yogyakarta. Learning Islamic Education is designed so that students feel comfortable, effective in learning and easy to understand the material delivered by the teacher.

The research conducted by Bahri in his opinion (1) behavioristic learning theories have a paradigm that only study the psychology of positive empirical, and eliminate the meaning of soul and ting practices. While in Islam the meaning of learning is to look at the soul and behavior of things that can not be separated. (2) Conditioning learning theory is a very low learning theory, in Ibn Meskavayh theory is only on strengthening the physical appetite and has not been able to power Al-Ghadabiyyat and which has the highest level is Al-Nathiqat. (3) The conditioning theory is old, because Ibn Sina discovered Talqin, the method of repeating to memorization and using habituation methods until they understood and memorized. (4) in Islam that gaining new knowledge or experience is resourceful and heart. Resourceful explaining something on the shutter is common and practical, sense is only capable of reaching empirical things. While the heart is able to understand something more deeply, both physical and metaphysical things (Bahri, 2017:196-213). Pratama shows that the relevance of behavioristic learning theory to Islamic education is in the study of Islamic religious education that behavioristic theory can be applied, the theory is in line and relates to Islamic teachings, and conditioning Classical, reinforcement and repetition of behavioristic theories are also used in the learning of Islamic education (Pratama, 2019:38-49). Classical Conditioning is a process of behavioral change with the direct stimulus, the stimulus given is a related stimulus so as to bring about the expected behavior (Sakinah, 2018:77). 


\section{B. METHODS}

This research is a research which is classified into a type of qualitative research with case study methods. This case study focuses on Islamic religious education subjects with the learning process using classical conditioning theory. Data collection in the form of observation results in class during the learning process, and interview results. The respondents in this study consisted of four people who were teachers of Islamic religious education class XII MIA VIII and three students in the class XII MIA VIII. Data analysis techniques are done by making a concept that is, look for review literature related to research objectives. After obtaining the data, the data is presented that is to sort the data according to the group and the withdrawal of conclusion is taken from the initial data to the end that has been collected and the withdrawal of conclusion.

\section{RESULT AND DISCUSSION}

\section{Implementation of Classical Conditioning in PAI learning}

Classical conditioning theory is used to transform positive attitudes to learners to be motivated to learn and train to students to perform positive habits that can develop their own potential. The application of classical conditioning theory is a teacher through methods of therapy aimed at changing the behavior of students to be more profitable. For example, fear of learning physics is transformed into a happy learning physics. Likewise, students who do not enjoy learning religion become happy to learn religion. A Classical Conditioning in the learning is a few things that PAI teachers do:

1. Learning design made interesting

PAI Learning at SMAN 1 Teladan is designed with a variety of teaching methods applied so students feel happy with learning. The teaching methods used are market pleces, discussions, presentations, and group investigations. Through the methods applied each lesson depends on the teacher in the use of teaching methods tailored to the circumstances of the student at the time of the study. In addition, the teacher positioned himself as a facilitator so that in PAI learning there was a response between teachers and students on learning. In this section, there are several steps performed by the teachers:

a. At the moment the teacher group discussions are silent and give students the freedom to express their opinions, so that the students are more interactive.

b. When describing the teacher material Berintermezo (slip jokes) so occasionally the students laugh.

c. Explanation of the material is in English, making students feel bored in learning.

d. Learning Media use. Learning process of Islamic education in SMAN 1 example using LCD, the Power point that show aims to give stimulus to the students so that the transfer of Knowledge (science) is not boring.

2. Continue Assignment

The task for students sometimes becomes a burden in itself that is capable of making them uncomfortable with learning. Many assignments make students feel unhappy about learning, but on PAI learning at SMAN 1 Yogyakarta example is made interesting so that each student feels it has a learning responsibility. The task of Kultum is given when the contract study with a predetermined theme, the theme is patience, sincere, and debt. The materials submitted by the student are complementary and may not repeat the same material. So according to students the task of Kultum given is a task that has a positive impact for us, will be a lot of new knowledge that we get and it is conveyed by friends with a dialect of language that is easy to understand IE as usual Daily. In addition, the task of Kultum gives students awareness. In the Kultum the steps are:

a. In the early stages of learning, students are required to stand before their friends and give the Kultum in accordance with the predetermined theme. The Kultum was delivered approximately 7-10 minutes per student, every study there were two students who were tasked with conveying the Kultum.

b. The task of the Kultum will make the inactive students become active. 
c. For less-active students, with the task of the Kultum will familiarize themselves in public.

Stimulus-stimulus given to students in the learning process of Islamic religious education is able to provide a positive response. The response gave the student more interactive stimulation in the discussion and gave self-awareness through the Kultum delivered by his friend.

\section{Factors affecting the implementation of classical conditioning in PAI learning}

In the implementation of the classical conditioning theory on PIE learning there are several factors that affect them:

1. Teacher Factors

Teachers as educators have the ability to determine correct teaching methods. In applying the classical conditioning method a teacher must be able to know the tendency of students or the psychology of the student so that the application of this theory can go well. Based on the results of observations made by teachers in teaching very familiar with the situation and condition and psychology of students, in addition PAI teachers have ideas and ideas to control the classroom atmosphere so as to support the application of theories Classical conditioning. When students do not ask the teacher to respond to the students for students to inquire through the explanation of the material, give students questions to the Ununderstood material and so on.

2. Student factors

The situation of students in SMAN 1 Yogyakarta's example in the learning process has a positive response, the tasks given by the teacher become the responsibility of each individual. The task given to students when finding the same theme then the student completes another assignment. Complementary and supportive attitudes that students do greatly influence the success of learning.

3. Institution (school) factors

SMAN 1 example is one of the schools in the special area of Yogyakarta. People often mention the school under the name of SMAN 1 exemplary. Based on the results of observations and interviews of authors on several speakers, students at the school have good manners. Polite, courteous, on everyone who is older than him. In addition, the form of the implementation of the school mission is the transparency and the ethics that instilled through schools that have a culture of religious norms, social society, and national norms.

Pavlov concludes that the results of experiments he can also apply to humans in learning. In human learning activities, the results of the experiment implicates that human learning activities fundamentally form an association between stimulus and reflective response. The learning process will take place when the conditional stimulus is given. So Pavlov shows that learning is an activity that can change human behaviour. Fundamentally classical conditioning is a procedure that creates new reflexes with the presence of the stimulus before the reflex (Syah, 2012:95). In this theory gave birth to two laws, namely Law of Respondent Conditioning and Law Of Respondent Extinction.

\section{Law of Respondent Conditioning}

The law of Respondent Conditioning is a required habituation law. If two types of stimulus are presented, the other one serves as a reinforcer, then the other reflexes and stimulus will increase. In learning will be sought in the habit of the students so that there is a continue learning process. According to Pavlov's theory of urgent learning is input in the form of stimulus and the outcome of response. The process that occurs between the stimulus and response is not so urgent noted because it is not observed and measured. Therefore, given by the teacher in the study of the knowledge-giving and the students who have been able to be observed and measured (Nahar, 2016:67). According to some learning experts include: 
1. Syaiful Sagala Learning is the process of teaching students using Azaz education as well as belar theory which is one of the main determinants of educational success.

2. Oemar Hamalik suggests a learning formula that is: (1) Learning is an environmental effort to create learning conditions for students. (2) Learning is an effort to prepare students to be good citizens. (3) Learning is a process that can help students face the lives of daily society. (4) The learning process in Islamic education

3. Miarso, Learning is an educational effort that is implemented purposely, with the purpose that has been tested first before the process is instituted, to be controlled (Ramayulis, 2018:338-340).

4. Gegne, learning is an external event in management to support the internal learning process. The meaning of learning that is able to produce learning, external conditions are management in such a way to support, maintain, and activate the internal processes contained in each event in learning (Siregar, 2014:12).

The educational psychology experts provide a fundamental step to the behavioristic aspects of learning (Abdriyani, 2015:174).

1. Stage of acquisition or acquisition of knowledge. At this stage students learn about new information.

2. Retention stage is a phase where new information or skills are practiced so that the student's memory is able to survive. This stage is called the Storange stage, which means that the learning results are stored to be used in the future.

3. Transfer stage, ideas that are backed up or stored in memory are sometimes difficult to recall when they will be used in the future. To do so, the ability to transfer them or recall in new learning requires an assortment of strategies. But the most important thing in remembering is valid information.

The Learning plan that is fundamental to the behavioristic theory has the assumption that knowledge is sure, fixed, unchanged, and objective. So learning is gaining knowledge. While teaching is the process of transferring or moving knowledge to the person who learns. Therefore, learning is expected to gain the same knowledge from those who transfer knowledge (Suyono \& Harianto, 2011:70). The application of learning theory in the learning process there are several measures which are offered by Woolfolk cited Nurhidayati .

1. Provide direction so that students are able to recognize the similarities and differences to situations, so they can group and efficiently be precise. E.g:

a. To provide confidence to students who are anxious to face exams when they want to go to higher-level schools or colleges, that the test has similarities to other academic performance tests they have ever traveled.

b. Provide understanding that avoiding excessive prizes of the unknown person is better or evasive but safe and get an award from an adult when the old the exists.

2. Provide a pleasant atmosphere when giving a learning task, by:

a. Emphasize the cooperation and race between groups from individuals, because most students will have a negative response to individual competitions that may be generally applied to other lessons.

b. Create a reading room that is conducive, comfortable, and interesting so that the reading activity becomes enjoyable.

3. To address the students in overcoming situations that are debased or depressing. For example, instructing students to teach other students to understand the subject matter. In addition, it provides weekly, daily tests so that students can learn about their abilities through test results. When students are afraid to speak then ask the SISW to read a report on a small group while sitting in place, then by standing. After he got used and not shy again ask to read the report in front of the entire student in the class (Nurhidayati, 2012:38-40). 


\section{Law of Respondent Extinction in PAI learning}

The law of Respondent Extinction is the required destruction law. When the reflex that has been strengthened through the respondent conditioning is brought back without presenting reinforces, the strength will be decreased. The point is in the learning process when teachers give a promise to the students to give gifts when they excel, but after the student has gained the achievement of the teacher does not give gifts so it can stimulate students ' psychology so as not to be active in learning.

Removal may apply when a regular stimulation is not followed by unusual stimuli, or an individual's organism or individuals will not respond or react. Once Repon is formed, the response will remain on the condition of providing conditional stimuli paired with an unconditional stimulus. When conditional stimulation is administered at a long time, then the conditional repon does not have an amplifier and it is likely that the conditional response will decrease the amount of its appearance or not be visible so this is called Blackout (extinction). Pavlov uses conditional terms on the results of the expression(Nurhidayati, 2012:30-31).

The Jozefowiez quoted by Huda explain three different meanings in the classical conditioning, which are procedures, learning phenomena observed in the same procedure, and the learning process that describes the phenomenon observed in the procedure It (Huda, 2017:18). This theory is therefore very suitable to be used in the learning process to change behaviours to students. The use of legal attenuation or destruction of students is done to the bad habits of students by giving the motivation of each learning process and giving a bad impact that the students will face. In addition, for students who violate the rules in the learning process are given penalties such as standing in front of the class while selfintrospective to their mistakes.

\section{CONCLUSION AND SUGGESTIONS}

The implementation of classical conditioning on PAI learning is done in several ways, and the atmosphere in the classroom is interesting. Through the combination teaching methods that apply teachers make students feel comfortable with learning. In addition, the assignment is continue to be given to students in the form of Kultum. As for the factors that affect them there are several factors, namely the teacher, Islamic religious education teacher at SMAN 1 Teladan of Yogyakarta has the ability to understand the appropriate stimulus used, in addition to the student factors that mutually support each other So that the process can be effective, and the institution or school factors that support in terms of means and policies that give free space to teachers to imagine creating effective learning.

\section{ACKNOWLEDGEMENT}

A thank you to related parties especially the principal of SMAN 1 exemplary who has given permission to researchers for conducting research in the institution. It doesn't expire to PAI teachers and some students willing to take the time to provide data on the interview process.

\section{REFERENCES}

Abdriyani, F. (2015). Teori Belajar Behavioristik dan Pandangan Islam tentang Behavioristik. Jurnal Syaikhuna, 1(1), 165-180.

Assegaf, A. R. (2014). Filsafat Pendidikan Islam. Jakartta: Raja Grafindo Persada.

Baharun, H. (2016). Pengembangan Media Pembelajaran PAI Berbasis Lingkungan Melalui Model ASSURE. Cendekia: Jurnal Kependidikan Dan Kemasyarakatan, 14(2), 231-246.

Bahri, S. (2017). "Paradigma Pembelajaran Conditioning dalam Pespektif Pendidikan Islam." Jurnal Tadris, $12(2), 196-213$.

Haslinda, H. (2019). Classical Conditioning. Network Media, 2(1), 87-99.

Hill, W. F. (2012). Theories of Learning: Teori-Teori Pembelajaran Konsepsi, Komparasi, dan Signifikasi. 
Bandung: Nusa Media.

Huda, M. M. (2017). Kolaborasi Teknik Insight, Modelling, Classical Conditioning, Sebagai Strategi Konselor dalam Pendidikan Karakter. Jurnal Psikopedagogia, 6(1), 14-21.

Nahar, N. I. (2016). Penerapan Teori Behavioristik dalam Proses Pembelajaran. Jurnal Nusantara, 1, 64-74. Nurhidayati, T. (2012). Implementasi Belajar Ivan Petrovich Pavlov (Classical Conditioning) dalam Pendidikan. Jurnal Falasifa, 3(1), 23-43.

Pratama, Y. A. (2019). Relevansi Belajar Behaviorisme dan Terhadap Pendidikan Agama Islam. Jurnal AlThoriqaah, 4(1), 38-49.

Ramayulis. (2018). Ilmu Pendidikan Islam. Jakarta: Kalam Mulia.

Rusuli, I. (2014). "Refleksi Teori Belajar Behavioristik dalam Perspektif Islam." Jurnal Pencerahan, 8(1), 38-54.

Sakinah, U. (2018). Konseling Behavioristik dalam Membentuk Perilaku Mandiri Merawat Diri pada Tunagrahita. Jurnal Hisbah, 15(1), 68-84.

Siregar, E. (2014). Teori Belajar dan Pembelajaran. Bogor: Penerbit Ghalia Indonesia.

Suyono, \& Harianto. (2011). Belajar dan Pembelajaran. Bandung.

Syah, M. (2012). Psikologi Belajar. Jakarta: Rajawali Pers.

Zamzani, M. R. (2015). Penerapan Reward and Punishment dalam Teori Belajar Behaviorisme. Ta'limuna, $4(1), 1-20$.

Zulhammi. (2015). Teori Belajara Behavioristik dan Humanistik dalam Perspektif Pendidikan Islam. Darul Ilmi, 3(1), 105-125. 